\title{
PLANT DIVERSITY IN HOMEGARDENS AND THEIR USE VALUE IN TWO VILLAGES OF RUPANDEHI DISTRICT, WESTERN NEPAL
}

\author{
Okmaya Srish, Chandra P. Pokhrel and Ram Kailash P. Yadav* \\ Central Department of Botany \\ Tribhuvan University, Kirtipur, Kathmandu \\ *E-mail: rkp.yadav@cdbtu.edu.np
}

\begin{abstract}
Homegardens play significant role in the livelihood of the rural people. The cultivation of different plants in homegardens for self-sufficiency has a long tradition worldwide, but knowledge about homegardens in Nepal is meager. To analyse this more deeply, cultivated plants of 15 homegardens were surveyed in two Village Development Committees (VDCs) in Tarai of Westren Nepal, viz. Anandavan and Karahiya VDCs. This study mainly focuses on the plant species diversity and their use values. Mostly perennial plants were included in the study. The plant studied in the homegardens included those which are used as fruits, fodder, medicine, nut and others. In Total, 31 plant species were found in the studied homegardens. Species diversity in the home gardens of Anandavan VDC was higher $\left(H^{\prime}=2.45\right)$ than that of Karhiya VDC $\left(H^{\prime}=2.19\right)$. The evenness of species, however, was not different in the homegardens of two VDCs.
\end{abstract}

Key words: Plant species diversity, fodder, fruits, medicine, homegarden.

\section{INTRODUCTION}

Homegarden, literally known in Nepali as 'Fulbari' refers to the traditional land use system around a homestead where different species of plants are grown and maintained by household members and their products are primarily intended for the family consumption (Shrestha et al. 2004). The homegarden provides a bridge between the social and biological, linking cultivated species and natural ecosystems, combining and conserving species diversity and genetic diversity (Eyzaguirre and Linares 2004). Homegarden is often considered synonymous to the kitchen garden; however, that differs in terms of function, size, diversity, composition and features (Sthapit et al. 2004). Homegarden agroforestry characterized by intensive integration of trees and shrubs with food crops and often animals is a predominant land use system in Kerala, India (Kumar and Nair 2004). Homegarden system is also important contribution to sustainable agricultural production, because of their potential to meet several economic, social, ecological and institutional conditions for sustainability (Torquebiau 1992, Nair 2001).

Agriculture, the main source of employment in rural countries, is facing three challenges to ensure food security, reduce poverty and promote sustainable management of natural resources. 
Homegardens are an important resource to enhance food security. The major benefits from home garden are better nutrition for the farmers; they receive income and meet socio-cultural needs. Along with these benefits, they help to reduce environmental pollution and soil erosion and to conserve the agro-biodiversity (Pulami et al. 2004).

Although practiced for a long time, the homegarden systems have been little studied, and most reported studies are descriptive and limited to the identification of plant species involved and location specific information on their yield and management (Nair 2001). Being an integral part of the Nepalese farming system and playing an important role in the livelihood of the community, scientific investigations on the status, roles, diversity and dynamics of homegardens are severely lacking (Subedi et al. 2004). Because of their small size, the government has never identified homegardens as an important source of food, fruits, firewood, timber, fodder production and it thereby remains neglected from research and development. The study was carried out to fulfill the following objectives: 1) to quantify the plant species grown in the homegarden area; 2) to document use value of species in the homegarden; and 3) to assess the plant species diversity of this land use system.

\section{MATERIALS AND METHODS}

\section{Study site}

The study was conducted in April 2011 in two Village Development Committees (VDCs), Karahiya and Anandavan in Rupendehi district in Tarai, Nepal. They are situated at the elevation of $200 \mathrm{~m}$ to $300 \mathrm{~m}$ asl, respectively. The area is favoured with hot and humid summer, and cool and dry winter. The average annual rainfall is 2288 $\mathrm{mm}$, and almost $1900 \mathrm{~mm}$ of this falls during monsoon months of June to September. The six months dry period, November to April, receives only about $300 \mathrm{~mm}$ of rain. The average monthly maximum temperature ranges from $22^{\circ} \mathrm{C}$ in January to $30^{\circ} \mathrm{C}$ in May, average monthly minimum temperatures vary from $11^{\circ} \mathrm{C}$ in January to $26^{\circ} \mathrm{C}$ in July. Soil of this study site is sandy, loamy, black and homogenous throughout the area.

\section{METHODS}

Household survey was conducted to collect information on plant species. Altogether fifteen households in Karahiya VDC and fifteen of Anandvan VDC having homegardens were sampled randomly among others. Different plant species that occurred within the homegardens were recorded. Plant species were categorized as fruits, medicine, fodder, spices, religious and nuts according to the information provided by the households and also key informants were consulted for additional information about the use of plants grown in the homegardens. Ornamental plants and vegetable species were not included. Plants identified in the field were recorded with their local as well as scientific names. Unidentified species were made herbarium and got identified at Central Department of Botany, Tribhuvan University.

The Shannon-Wiener index was calculated to assess the species diversity in homegardens of two VDCs and index of species evenness was also determined to analyse the equitability of occurrence of species across the homegardens following the equations used by Wezel and Bender (2003).

\section{RESULTS AND DISCUSSION}

A total of 31 different plant species that were recorded in homrgardens of both VDCs are summarized in Tables 1 and 2. Their Nepali name, habit and preferred use values are also given according to the information supplied by people. 
Most of the homegardens display three vegetation layers making them typical agroforestry system (de Clerck and Negreros-Castillo 2000). In the present study, the top layer (3-10 m) consisted mostly of trees such as mango (Mangnifera indica), Sisso (Dalbergia sisso), Rukhkatahar (Artocarpus heterophylus), Aaru (Prunus persica) etc. In the middle layer (1-3 m), smaller trees like Guava (Psidium guajava), Lemon (Citrus aurantifolia), Papaya (Carica papaya) etc. are the major species. In the ground layer (0-1 m), mainly smaller herbaceous spices such as Acorus calamus, Aloe barbedensis, etc are present.
Of the total 15 homegardens studied in each of the two VDCs, 31 plant species belonging to 21 families were recorded in the homegardens of Anandvan VDC and 15 plant species belonging to 12 families were recorded in the homegardens of Karahiya VDC (Tables 1 and 2). Species diversity of Anandvan VDC was higher $\left(H^{\prime}=2.45\right)$ than that in Karahiya VDC $\left(H^{\prime}=2.19\right)$. In both VDCs, evenness of total species distribution was higher in Karahiya VDC (Table 3). With respect to species groups, fruit trees were most whereas medicines and other species were least distributed.

Table 1. Enumeration of plant species and use value in the homegardens of Anandvan VDC.

\begin{tabular}{|c|c|c|c|c|}
\hline SN & Nepali name & Botanical name & Family & Use value \\
\hline 1. & Dabdabe & Garuga pinnata Roxb. & Burseraceae & Fodder \\
\hline 2. & Ipil-Ipil & Leucaena leucocephala $\mathrm{L}$. & Leguminosae & Fodder \\
\hline 3. & Kabhro & Ficus lacor Buch-Ham. & Moraceae & Fodder \\
\hline 4. & Kimbu & Morus alba L. & Moraceae & Fodder \\
\hline 5. & Dumre & Ficus racemosa $\mathrm{L}$. & Moraceae & Fodder \\
\hline 6. & Simal & Bombax ceiba L. & Bombacaceae & Fodder \\
\hline 7. & Sissoo & Dalbergia sisso Roxb. & Leguminosae & Fodder \\
\hline 8. & Anaar & Punita granatum $\mathrm{L}$. & Punicaceae & Fruit \\
\hline 9. & Aanp & Magnifera indica $\mathrm{L}$. & Anacardiaceae & Fruit \\
\hline 10. & Aaru & Prunus persica $\mathrm{L}$. & Anacardiaceae & Fruit \\
\hline 11. & Amba & Psidium guajava $\mathrm{L}$. & Myrtaceae & Fruit \\
\hline 12. & Bhogate & Citrus maxima Merr. & Rutaceae & Fruit \\
\hline 13. & Jamun & Syzygium cumuni L. & Myrtaceae & Fruit \\
\hline 14. & Kagati & Citrus aurantifolia Swingle & Rutaceae & Fruit \\
\hline 15. & Kera & Musa paradisiaca $\mathrm{L}$. & Musaceae & Fruit \\
\hline 16. & Litchi & Litchi chinensis Sonn. & Sapindaceae & Fruit \\
\hline 17. & Mewa & Carica papaya $\mathrm{L}$. & Carcaceae & Fruit \\
\hline 18. & Naspati & Pyrus communis $\mathrm{L}$. & Rosaceae & Fruit \\
\hline 19. & Rukh katahar & Artocarpus heterophylus L. & Moraceae & Fruit \\
\hline 20. & Bojho & Acorus calamus $\mathrm{L}$. & Araceae & Medicinal \\
\hline 21. & Ghiukumari & Aloe barbadensis Mill. & Liliaceae & Medicinal \\
\hline 22. & Marhatti & Ocimum basilicum $\mathrm{L}$. & Lamiaceae & Medicinal \\
\hline 23. & Neem & Azadirachta indica A. Juss. & Meliaceae & Medicinal \\
\hline 24. & Tulsi & Ocimum tenuiflorum $\mathrm{L}$. & Lamiaceae & Medicinal \\
\hline 25. & Titepati & Artemesia indica Willd. & Compositae & Medicinal \\
\hline 26. & Nariwal & Cocos nucifera $\mathrm{L}$. & Palmae & Nut \\
\hline 27. & Supari & Areca catechu $\mathrm{L}$. & Palmae & Nut \\
\hline 28. & Bel & Aegle marmelos L. & Rutaceae & Fruit \\
\hline 29. & Aangoor & Vitis vinifera $\mathrm{L}$. & Rutaceae & Fruit \\
\hline 30. & Kapas & Gossipium arboretum L. & Malvaceae & Fibre \\
\hline 31. & Ukhu & Saccharum officinarum $\mathrm{L}$. & Poaceae & Juice \\
\hline
\end{tabular}


Table 2. Enumeration of plant species and use value in the homegardens of Karahiya VDC.

\begin{tabular}{|c|c|c|c|c|}
\hline $\mathbf{S N}$ & Nepali name & Botanical name & Family & Use value \\
\hline 1. & Lipil-lipil & Leucaena leucocephala $\mathrm{L}$. & Leguminosae & Fodder \\
\hline 2. & Kimbu & Morus alba $\mathrm{L}$. & Moraceae & Fodder \\
\hline 3. & Sisso & Dalbergia sisso Roxb. & Leguminosae & Fodder \\
\hline 4. & Aanaar & Punita granatum $\mathrm{L}$. & Punicaceae & Fruit \\
\hline 5. & Aanp & Magnifera indica $\mathrm{L}$. & Anacardiaceae & Fruit \\
\hline 6. & Aaru & Prunus persica $\mathrm{L}$. & Rosaceae & Fruit \\
\hline 7. & Amba & Psidium guajava $\mathrm{L}$. & Myrtaceae & Fruit \\
\hline 8. & Ukhu & Saccharum officinarum $\mathrm{L}$. & Poaceae & Religious \\
\hline 9. & Kera & Musa paradisiaca $\mathrm{L}$. & Musaceae & Fruit \\
\hline 10. & Litchi & Litchi chinensis Sonn. & Sapindaceae & Fruit \\
\hline 11. & Mewa & Carica papaya $\mathrm{L}$. & Carcaceae & Fruit \\
\hline 12. & Naspati & Pyrus communis $\mathrm{L}$. & Rosaceae & Fruit \\
\hline 13. & Rukhkatahar & Artocarpus heterophylus L. & Moraceae & Fruit \\
\hline 14. & Bojho & Acorus calamus L. & Araceae & Medicinal \\
\hline 15. & Neem & Azadirachta indica A.Juss & Meliaceae & Medicinal \\
\hline
\end{tabular}

Plant species in the homegardens serve many uses in Anandavan VDC. Majority are used as fruit $(45 \%)$, followed by fodder $(22 \%)$, medicine (19\%), nut (6\%), fibre (3\%) and juice (3\%). Similarly managed plant species serve many uses in Karhiya VDC also (Fig. 2). Majority are used as fruit $(60 \%)$, fodder $(20 \%)$, medicine $(13 \%)$ and for religious purpose $(6 \%)$.

Table 3. Plant species diversity indices of homegardens in two VDCs.

\begin{tabular}{lcc}
\hline Study sites & $\begin{array}{c}\text { Shannon- } \\
\text { Wiener } \\
\text { Index (H') }\end{array}$ & $\begin{array}{c}\text { Evenness } \\
\text { Index } \\
(\mathbf{E})\end{array}$ \\
\hline Anandvan VDC & 2.45 & 0.71 \\
Karhiya VDC & 2.19 & 0.81 \\
\hline
\end{tabular}

A broad range of fruit plants in the homegardens covers about $45 \%$ of the total plant species. Main fruit trees grown in homegardens include guava, mango, litchi, etc. Different types of medicinal plants are grown in homegardens. Here, local people's knowledge seems to play an important role. During the study, six species of medicinal plants, out of 31 plant species, were recorded in the homegardens.
Both the VDCs are inhabitated by Magar, Gurung and Brahmin communities. They manage the seeds for homegardens from forest, market and sharing from their savings. They weed their homegarden on an almost regular basis, basically to prevent invasion of pests such as insects, rodents and reptiles. In order to increase yield and fertility of soil, farmyard manure and compost are used. From the homegarden, products are usually not sold because most species are exclusively used for self consumption or used as animal feed. Local people also keep livestock which include pig, goat, cow, buffalo, etc. In order to feed them they have planted different types of fodder plants. About seven fodder plant species were recorded from the study area.

Apparently, there exists a rough correlation between the life form of managed plants and their utility. Plants with a tree habit are more likely to be managed for their overall and food usefulness, whereas herbs are more popular as medicines. The fact that trees possess the highest mean overall use value of all managed life forms is basically due to their more complex habit and multipurpose nature, apart from fulfilling human needs for food and

ECOPRINT VOL 18, 2011 
medicine they also contribute considerably as sources of materials and fuel (Thomas and Damme 2010). Of all the services provided, the most important use of trees is for food (mostly fruits). The reason might be that trees are long lived, diverse food and require less labour for their care. But, managed herbs in the homegarden have the highest mean medicinal value of all life forms. The homegarden also aims to strengthen local communities and help build peaceful communities. Homegardens may offer a viable platform to institute solidarity, social justice and equity, especially for the disadvantaged and vulnerable sections of the population (Galhena et al. 2012).

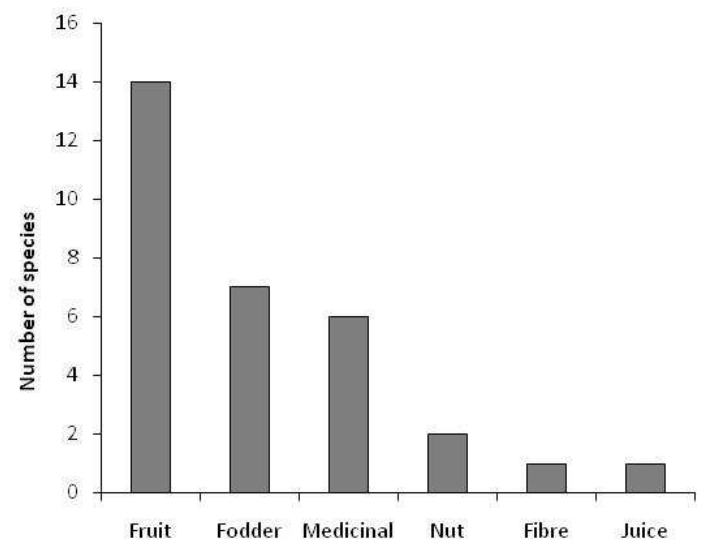

Fig. 1. Number of plant species in different uses in the Anandavan VDC

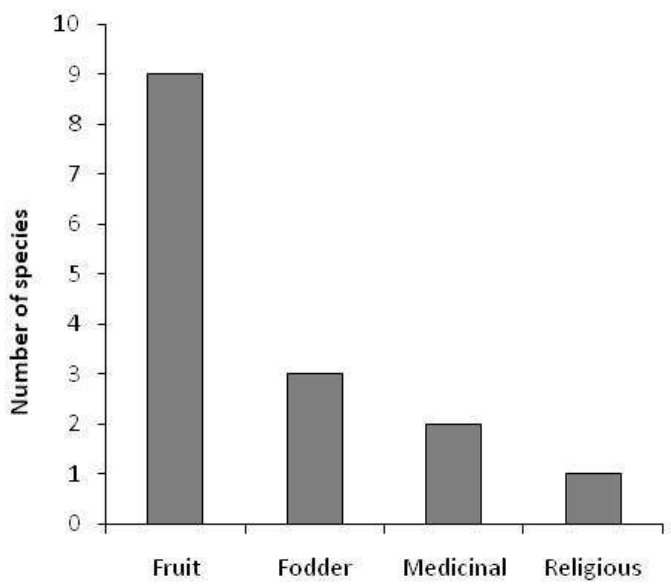

Fig. 2. Number of plant species in different uses in Karhiya VDC.
It can be concluded that homegarden plays a central role in the livelihood of local people of Anandavan and Karhiya VDCs in Tarai districts of Nepal. High plant species diversity in homegardens contributes a lot in different services. Further, they can contribute to sustainable land use because pressure on fragile land or forested areas can be reduced (Wezel and Bender 2003). More detailed study is still needed to explore the information about the plant species diversity and management of homegardens.

\section{ACKNOWLEDGEMENTS}

O. Shrish extends her sincere gratitude to the people of Karahiya and Anandavan VDCs for their generous cooperation during field study.

\section{REFERENCES}

de Clerck, F.A.J. and P. Negreros-Castillo. 2000. Plant species of traditional Mayan homegardens of Mexico as analogs for multistrata agroforests. Agroforestry Systems 48:303-317.

Eyzaguirre, P. and O. Linares. 2004. Introduction. In: Homegardens and Agro-biodiversity. (eds.) Eyzaguirre, P. and O. Linares. Smith-sonian Books, Washington, pp. 1-28.

Galhena, D.H., G. Mikunthan and K. Maredia. 2012. Home gardens for enhancing food security in Sri Lanka. Farming Matters 28(2): 12 .

Gebauer, J. 2005. Plant species diversity in home gardens of EI obeid, Central Sudan. Journal of Agricultural and Rural Development in the Tropics and Subtropics 106(2):97-103.

Kumar, B.M. and P.K.R. Nair. 2004. The enigma of tropical homegardens. Agroforestry Systems 61:35-152.

Nair, P.K.R. 2001. Do tropical homegardens elude science, or is it the other way around? Agroforestry Systems 53(2):239-245. 
Pulami, R.P. and D. Poudel. 2004. Contribution of homegarden to livelihoods of nepalese farmers. In: Home Gardens in Nepal. Proceedings of a National Workshop. (eds.) Gautam, R., B. Sthapit and P. Shrestha. Pokhara, Nepal, pp. 18-26.

Regmi, B.R., K.P. Aryal, B.B. Tamang and P.K. Shrestha. 2004. Home gardens: an opportunity to minimize pressure on slash and burn system and option for improving dietary diversity of Chepang households. In: Home Gardens in Nepal. Proceedings of a National Workshop. (eds.) Gautam, R., B. Sthapit and P. Shrestha. Pokhara, Nepal, pp. 35-47.

Shrestha, B.P. 1989. Forest Plants of Nepal. Educational Enterprisise Pvt Ltd., Kathmandu, pp. 171-210.

Shrestha, P.K., R. Gautam and B. Sthapit. 2004. Manistreaming findings of home garden project for on-farm biodiversity management and improving livelihoods: Policy and programme implications. In: Home Gardens in Nepal. Proceedings of a National Workshop. (eds.) Gautam, R., B. Sthapit and P. Shrestha. Pokhara, Nepal, pp. 119-125.
Sthapit, B., R. Gautam and P. Eyzaguirre. 2004. The value of Home garden to small farmers. In: Home Gardens in Nepal. Proceedings of a National Workshop. (eds.) Gautam, R., B. Sthapit and P. Shrestha. Pokhara, Nepal, pp. 817.

Subedi, A., R. Suwal, R. Gautam, S. Sunwar and P.K. Shrestha. 2004. Status and composition of genetic diversity in nepalese homegarden. In: Home Gardens in Nepal. Proceedings of a National Workshop. (eds.) Gautam, R., B. Sthapit and P. Shrestha. Pokhara, Nepal, pp. 72-83.

Thomas, E. and P.V. Damme. 2010. Plant use and management in homegardens and swiddens: Evidence from the Belvian Amazon. Agroforestry Systems 80:131-151.

Torquebia, E. 1992. Are tropical agroforestry homegardens sustainable? Agriculture, Ecosystems and Environment 41:189-207.

Wezel, A. and S. Bender. 2003. Plant species diversity of home gardens of Cuba and its significance for household food supply. Agroforestry Systems 57:39-49. 